\title{
Response of Some Yellow Maize Crosses to N- fertilizer Rates and Plant Densities at Toshka Region
}

\author{
A. Awadalla and A. S.M. Morsy \\ Department of Agronomy, Faculty of Agriculture and Natural \\ Resources, Aswan University, Aswan, Egypt.
}

\begin{abstract}
7 IELD studies were conducted at Toshka region, South Valley of Egypt, during the summer seasons of 2014 and 2015 to evaluate the some yellow maize single crosses, i.e. SC-162, SC-168 and SC176 under three plant densities of $(21000,27300$ and 33600 plant/fad) and three levels of nitrogen fertilizer $(90,120$ and $150 \mathrm{Kg} \mathrm{N} / \mathrm{fad})$. The results showed that $\mathrm{N}$ - levels were affected significantly all characters under study, i.e. growth characters, grain yield, protein content and the nitrogen use efficiency (NUE), except leaf area of the top most ear/plant. The application of $150 \mathrm{~kg} \mathrm{~N} /$ fad was resulted significant increase in grain yield and estimated by 4340 and $4235 \mathrm{~kg} / \mathrm{fad}$ in 2014 and 2015, respectively. The plant densities also exhibited significant effect on the studied characters, except leaf area of the top most ear/plant, ear length, ear diameter, number of grains/row and protein content. The increasing of plant density from 21,000 to 33,600 plant/fad increased the grain yield up to 13.44 and $17.27 \%$ in 2014 and 2015 seasons, respectively. The single crosses of maize differed significantly for ear length, NUE and grain yield during the 2014 season and the hybrid SC-176 recorded the highest value for grain yield of $4246.6 \mathrm{~kg} / \mathrm{fad}$.
\end{abstract}

The interaction $\mathrm{N}$ levels $\mathrm{x}$ plant densities interaction were significant for plant height and NUE in both seasons and grain yield in the 2015 season. The plant density x maize crosses interaction were significantly also for ear length, grain yield and NUE in the 2014 season and the 500-grain weight in the 2015 season. Moreover, significant interaction among the three factors for grain yield and NUE through the 2014 season and stem diameter in 2015 season.

The economic evaluation showed that the highest net return obtained from sowing SC-176 cross by plant density of 33600 plant/fad and supplemented by $150 \mathrm{~kg} \mathrm{~N} / \mathrm{fad}$.

Keywards: Nitrogen fertilizer, Cultivars, Plant densities

Toshka is one of the cultivated areas of the south valley of Egypt. This area is differs in its soil particle distribution, chemical analyses and its fertility as well as climatic conditions than both of Delta and Nile valley areas (Soliman et al., 2005). Maize is one of the most strategically crop in Egypt. To cover the shortage in human needs, animal and poultry feeding from maize grain for many purposes such as bread making ( $20 \%$ of maize flower mixed with $80 \%$ wheat flower to reduce the imported 
quantity of wheat) and using high yielding hybrids make big yield productivity. Lamkey (1994), EL-Agamy et al. (1999) and Soliman et al., (2005) found that at least $50 \%$ of the observed increase in grain yield is due mainly to sowing new hybrids of maize.

Agronomic practices i.e. nitrogen fertilization and plant densities and others also play important roles in maize production. Increasing plant densities markedly increased grain yield per unit and vice versa decreased plant height, number of ears/plant and grain yield/plant and delays pollen shedding and tassel appearance as reported by Tantawy et al.(1998), EL-Agamy et al.(1999) and Soliman et al. (1999 and 2005)

Widdicombe \& Thelen (2002) found that increasing plant density from 56000 to 90000 plants/ha significantly increased grain yield from 10.536 to 11.683 tons/ha, respectively.

Nitrogen plays a vital role in nutritional and physiological status of plants, promotes changes in mineral composition of plant, and is the most important element for plant growth and development. Increasing nitrogen fertilizer rates up to certain levels delayed pollen shedding and silking dates and increased plant height, number of leaves per plant, LA, LAI and grain yield per unit area (Abdrabou et al., 1996; Hussein et al., 1998; El-Agamyet al., 1999; Zeidan et al., 2006 and Ayman \& Samier, 2015) . Nitrogen deficiency or excess can result in reduced maize yields. Maize nitrogen requirement depends upon many factors i.e. cultivar used, soil health and others. However, the amount of optimum nitrogen fertilizer varies cultivars and ecological conditions (Sencer, 1988; Sezer \&Yanbeyi, 1997; Kirtok,1998; Karasu, 2012 and Nasser et al., 2015).

Study is aimed at evaluation the response of some yellow maize crosses to nitrogen levels under different plant densities as well as their interactions under Toshka Region, South Valley, Egypt.

\section{Materials and Methods}

Two field experiments were conducted at South Valley Farm Research Station, Toshka Region, Agriculture Research Center during 2014 and 2015 seasons. The physical and chemical analyses of the soil were done, results presented in Table 1 .

The experimental design was a split-split plot design with three replications. Three nitrogen fertilizer rates of 90,120 and $150 \mathrm{~kg} \mathrm{~N} / \mathrm{fad}$ (faddan $=4200 \mathrm{~m}^{2}$ ) were distributed in main plots, three plant population densities of 5, 6.5 and 8 plants $/ \mathrm{m}^{2}$ (providing a plant population densities of 21000,27300 and 33600 plants/fad, respectively) arranged in the sub-plots and the three yellow maize single crosses (i.e. SC-162, SC-168 and SC-176) allocated in sub-sub plots. Drip irrigation system was followed and water requirements were applied according to Soliman et al.(2004). Plots consisted of 4 rows, $6 \mathrm{~m}$ long and one -meter width and 30cm apart between drippers. Nitrogen was applied in four split applications : $1^{\text {st }}$ after thinning Egypt. J. Agron. 38, No. 3(2016) 
(18 days from sowing (DAS), $2^{\text {nd }} 30$ DAS, $3^{\text {rd }} 40$ DAS and $4^{\text {th }} 50$ DAS . Used in the form of ammonium nitrate $(33.5 \% \mathrm{~N})$ as a solution with water irrigation . Seeds were hand sowing in hills around the drip point on August $1^{\text {st }}$ in both seasons and thinned to one plant/hill. All plots were irrigated two hours daily. Hoeing was practiced twice after 18 and 30 days from sowing. At harvest, plants were taken from two inner rows for recorded the following growth observations :

TABLE 1. Physical and chemical analyses of the soil sites in 2014 and 2015 seasons at Toshka Region in 2014 and 2015 seasons.

\begin{tabular}{|c|c|c|c|c|}
\hline \multirow{3}{*}{ Soil characters } & \multicolumn{2}{|c|}{2014 season } & \multicolumn{2}{|c|}{2015 season } \\
\hline & \multicolumn{4}{|c|}{$\begin{array}{l}\text { Soil depth }(\mathrm{cm}) \\
\end{array}$} \\
\hline & $0-30$ & $30-60$ & $0-30$ & $30-60$ \\
\hline \multicolumn{5}{|c|}{ Soil particle distribution } \\
\hline Sand (\%) & 67.0 & 51.5 & 65.8 & 51.9 \\
\hline Clay (\%) & 3.3 & 9.5 & 3.2 & 9.6 \\
\hline Silt (\%) & 29.7 & 39.0 & 31.0 & 38.5 \\
\hline Texture & Sand loam & Loam & Sand loam & Loam \\
\hline \multicolumn{5}{|c|}{ Soil chemical characteristics and soil fertility conditions } \\
\hline $\mathrm{PH}$ & 9.10 & 9.10 & 9.11 & 9.2 \\
\hline $\mathrm{EC}(\%)$ & 0.04 & 0.03 & 0.04 & 0.03 \\
\hline CEC (meg/100 g) & 14.80 & 15.00 & 15.00 & 16.00 \\
\hline $\mathrm{Ca} \mathrm{Co}_{3}(\%)$ soil & 12.80 & 13.80 & 11.90 & 12.10 \\
\hline $\mathrm{N}(\mathrm{ppm})$ & 25.00 & 20.00 & 23.00 & 24.00 \\
\hline $\mathrm{P}(\mathrm{ppm})$ & 6.00 & 5.00 & 5.50 & 5.50 \\
\hline $\mathrm{K}(\mathrm{ppm})$ & 160.00 & 160.00 & 166.0 & 165.00 \\
\hline $\mathrm{Fe}(\mathrm{ppm})$ & 10.00 & 12.00 & 10.00 & 11.00 \\
\hline $\mathrm{Zn}(\mathrm{ppm})$ & 0.18 & 0.15 & 0.20 & 0.15 \\
\hline $\mathrm{Mn}(\mathrm{ppm})$ & 4.00 & 4.00 & 4.00 & 4.00 \\
\hline $\mathrm{Cu}(\mathrm{ppm})$ & 0.10 & 0.20 & 0.25 & 0.18 \\
\hline B (ppm) & 0.80 & 0.90 & 0.80 & 0.80 \\
\hline
\end{tabular}

Growth parameters

1-Plant height, $\mathrm{cm}$.

2-Ear height, $\mathrm{cm}$.

3-Number of green leaves/plant

4-Leaf area of the top-most ear/plant $\left(\mathrm{dm}^{2}\right)$. According to Alessi \& Power (1975) as the following formula:

Leaf area $=$ leaf length $\mathrm{x}$ maximum width $\mathrm{x} 75 \%$.

5-Leaf area index (LAI) : It was calculated as the ratio by dividing the mean of the leaf area of five plants $\left(\mathrm{cm}^{2}\right)$ by occupied area by the plants (Diwaker \& Oswalt, 1992).

6-Stem diameter, $\mathrm{cm}$ : Stem diameter of the second inter node in $\mathrm{cm}$ using venire caliperation method.

Yield and yield components

1- Ear length and ear diameter, $\mathrm{cm}$. 
2- Number of rows/ear and number of grains/row.

3- Grains weight/ear, g. adjust grain yield per plot/number of plants per plot.

4- 500-grainsweight, g. adjusted to $15.5 \%$ moisture.

5- Grain yield (ard. /fad.): it was measured from the weight of grains adjusted to 15. $5 \%$ moisture of each plot and converted to ardabs/ faddan (One ardab $=140 \mathrm{~kg}$ ).

6- Nitrogen use efficiency (NUE):( $\mathrm{kg}$ grain / $\mathrm{kg} \mathrm{N}$ applied)

Grain nitrogen use efficiency (NUE) (Barbar,1976) was calculated as follows :

$$
=\frac{\text { Grain yield }}{N \text { applied }}
$$

Crud protein in grains

It was measured by using procedure of Microkeldahel as described by Cottenie et al. (1982).

Economic evaluation

In present study, the economic evaluation included four items as follows:

1-Total costs of yield

2-Total net return (Gross return) of yield production: Total net farm income is the value of yield according to the actual price (The price of grain yield was 350 L.E. /fad) as given by Extension Service Information, Ministry of Agriculture .

3-Net farm return (Profit) $=$ Gross INC - Cost.

$4-$ Benefit cost ratio $(\mathrm{BCR})=\frac{\text { Profit }}{\text { Cost }}$

Economic valuation was done using the method described by CIMMYT. (1988).

Statistical analysis

Analysis of variance was done according to procedures outlined in Gomez \& Gomez (1991). Means were compared using LSD at 5\% levels of probability as revealed by Steel et al.(1997).

\section{Results and Discussion}

Effect of nitrogen levels on growth parameters, maize grain yield and its attributes Growth parameters

It is cleared that plant height increased significantly as nitrogen rates were increased from 90 to $150 \mathrm{kgN} / \mathrm{fad}$ in both growing seasons (Table 2). This increase may be due mainly to the role of nitrogen as a constituent of all proteins and nucleic acids which led to increase cells number and size which in turn encourage the elongation of the internodes of the stem. Similar results were obtained by ElAgamy et al.(1999), Abdel-Hameed (2005), Zeidan et al. (2006), Akmal et al. (2010), Karasu (2012), Aiad et al. (2014), Shahid et al. (2014) and Nassr et al. (2015).

Egypt. J. Agron. 38, No. 3(2016) 
Moreover, the data in Table 2 showed that the increasing of nitrogen fertilizer rates from 90 to $150 \mathrm{kgN} /$ fad resulted in significant increase in number of green leaves/plant and leaf area index in both growing seasons. The results may be attributed to increasing the amount of absorbed $\mathrm{N}$ by plants especially to early growth stage, which led to increase cell number and size and allowed maintaining the oldest leaves healthy. These results are in accordance with reported by EL-Agamy $e t$ al. (1999), Adel-Hameed (2005) and Akmal et al. (2010).

\section{Yield attributes}

Results presented in Table 3 show the effect of $\mathrm{N}$-fertilizer rates on the yield attributes (i.e. ear length and diameter, number of grains/row, 500 grains weight of grains weight/plant) during the two growing seasons. Raising $\mathrm{N}$ fertilizer rates from 90 to 120 and doubling the rate from 60 to $150 \mathrm{~kg} / \mathrm{fad}$ were accompanied by a significant increase of aforementioned traits. These increase in accounted for ear length as 7.77 and $12.04 \%$ in the first and 5.28 and $17.19 \%$ in the second season, 500-grains weight as 7.39 and $11.45 \%$ in the first and 6.57 and $13.05 \%$ in the second season, grains weight/plant as 7.50 and $14.61 \%$ in the first and 5.02 and $11.13 \%$ in the second season, number of grain/row of 3.17 and $10.45 \%$ in the first season and ear diameter 4.43 and $13.79 \%$ in the second, respectively. The corresponding values of crud protein in grains were 10.06, 11.02 and 11.52 in the first season and 10.01, 10.93 and 11.94 in the second season, respectively. The increment in 500 grains weight as a result of increasing $\mathrm{N}$-fertilization rate may be due to the role of nitrogen in increasing plant growth and grain filling. Meanwhile, in grain yield due to nitrogen fertilizer may be explained by the increase in most correlated yield components, which increase the final yield. The increase of protein percentage due to high $\mathrm{N}$ content by maize grains under high rates of $\mathrm{N}$-fertilizer. This might be attributed firstly to the increases in the root surface and enrichment of soil solution with nitrogen which reflects its influence on $\mathrm{N}$-concentration in plant tissues. This raising in N\% in plant tissues may be contributed in building up metabolites and subsequently increasing dry matter production up to full growth stage and thin increases nutrients uptake by maize plant. The previous results are in accordance with those reported by EL-Agamy (1999), Abdel-Hameed (2005), Zeidan et al., (2006), Akmal et al. (2010), Karasu (2012), Aiad et al. (2014), Shahid et al. (2014) and Nassr et al. (2015).

\section{Grain yield ( $k g / f a d)$}

The data in Table 3 indicated that grain yield was significantly increased as nitrogen fertilizer rates increased up to $150 \mathrm{kgN} / \mathrm{fad}$ in both growing seasons. The percentages of increase in grain yield due to application of 120 and $150 \mathrm{kgN} / \mathrm{fad}$ relative to $90 \mathrm{kgN} /$ fad were 3.80 and $9.19 \%$ in 2014 season, and 4.80 and $8.46 \%$ in 2015 season, respectively. The results may be due to the fact that nitrogen fertilization create strong and healthy plants which resulted in increasing the vegetative growth related to the source capacity of maize plants, i.e. plant height, leaf number/plant, leaf area/plant and LAI. These results are in harmony with those obtained by EL-Agamy et al. (1999), Abdel-Hameed (2005), Zeidan et al., (2006), Akmal et al., (2010), Karasu (2012), Aiad et al. (2014), Shahid et al. (2014), Nassr et al. (2015) and Hafez \&Abdelaal (2015). 


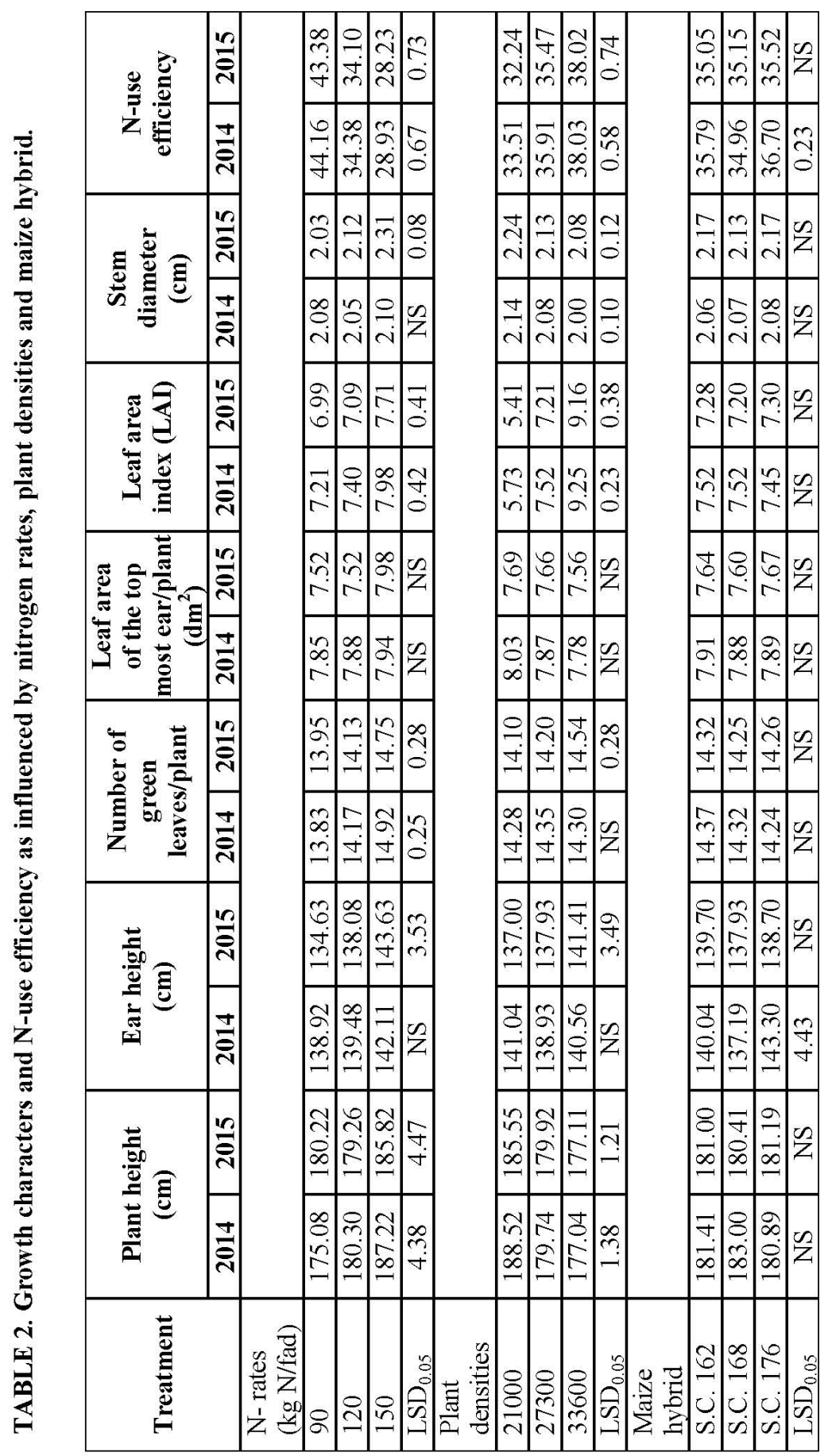

Egypt. J. Agron. 38, No. 3(2016) 
RESPONSE OF SOME YELLOW MAIZE.......

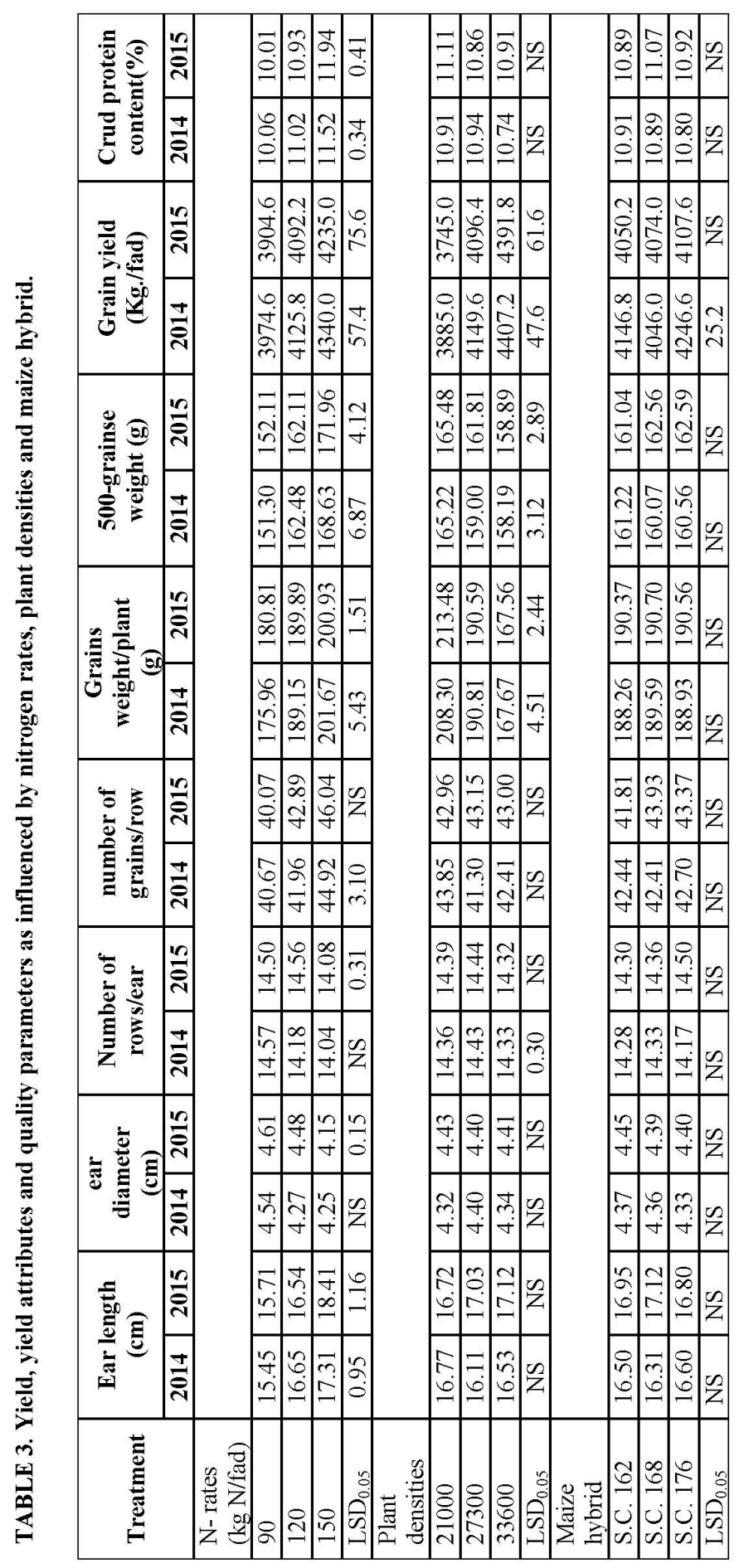

Egypt. J. Agron. 38, №. 3 (2016) 
Effect of plant densities on growth parameters and maize grain yield and its attributes: Growth characters

Plant height is an important component which helps for determining the growth attained during the growing period. The data showed that plant height was significantly affected by plant population (Table 2). Planting maize under high density of 33600 plants/fad gave the shortest plants of $177.04 \mathrm{~cm}$ in the first season and $177.11 \mathrm{~cm}$ in the second season. The tallest plants of 188.52 and $185.55 \mathrm{~cm}$ were recorded in 2014 and 2015 seasons, respectively, due to crowding effect of the plant and higher intra-specific competition for resources. This trend explains that as the number of plants increased in a given area the competition among the plants for nutrients uptake and sunlight interception also increased (Sangakkara et al., 2004 and Abuzar et al., 2011). Results presented in Table 2 show that increasing plant population densities 21000 to 27300 and 33600 plants/fad significantly increased the ear height and number of green leaves/plant in 2015 season and LAI in both seasons, but reduced stem diameter in both growing seasons. The increase of ear height, number of green leaves/plant and LAI by increasing plant population densities were mainly to that the reduction in leaf area/plant. Previous research findings also indicated that in high maize density, leaf area index, total dry weight and crop growth rate increased than low maize density throughout crop growth season (Saberali, 2007; ELMetwally et al., 2011 and Abuzar et al., 2011).

\section{Yield attributes}

The influence of plant density on selected plant parameters, i.e. number of rows/ear, grains weight/plant and 500 grains weight is presented in Table 2. Plant population density had significant effects on the number of rows/ear in 2014 only, grains weight/plant and 500 grains weight in both seasons.

Number of rows/ear in 2014 was increased significantly by increased plant density from 21000 to 27300 plants. Planting 27300 plant/fad had the highest number of rows/ear, while planting 33600 plant/fad recorded the lowest number of rows/ear. Mohammed (1999) found that ear length, ear diameter, number of rows/ear, number of kernels/row and 100-kernels weight decreased with increasing plant densities from 20 to 35 thousand plants/fad. Increasing plant density from 21000 to 33600 plants/fad reduced grains weight/plant by 19.51 and $21.51 \%$ in 2014 and 2015 seasons, respectively. Also, increasing plant density from 21000 to 27300 plant/fad reduced grains weight/plant by 8.40 and 10.72 in 2014 and 2015 seasons, respectively. The reduction in grains weight/plant by increasing plant density may be due to interplant competition. High plant densities delay silk emergence that lead to decrease in grain number/ear and reduction in total grain yield. Edmeades et al. (2000) found that high plant densities enhance interplant competition for assimilates, particularly during the period bracketing silking, favoring epical dominance and decreasing the ratio of ear to tassel growth rate. Similar results were reported by Zeidan et al. (2006), Maddonni et al. (2006), Shakarami \& Rafiee (2009), Gozubenli (2010), EL-Metwally et al. (2011) and Sarwar et al. (2016).

Egypt. J. Agron. 38, No. 3(2016) 
Grain yield $(\mathrm{kg} / \mathrm{fad})$

Respecting plant population densities (Table 3) showed that significant increase was obtained from 3885.0 to 4149.6 and $4407.2 \mathrm{~kg} / \mathrm{fad}$ in the first and from 3745.0 to 4096.4 and $4391.8 \mathrm{~kg} / \mathrm{fad}$ in the second seasons when the plant population densities were increased from 21000 to 27300 and 33600 plants/fad, respectively. The current results could be attributed to the increase in LAI at the highest plant population densities which permit maize plant to intercept more solar radiation and increase the photosynthetic activity per unit area of the canopy, which was converted well to dry matter accumulation in case of dense planting. Therefore, 27.3 to 33.6 thousand plants/fad is considered to be adequate to produce the highest grain yield under Toshka, South valley of Egypt. These findings agree with those of several previous studies such as EL-Agamy et al. (1999), Farnham (2001), Widdicombe \& Thelen (2002), Amer et al. (2004), Soliman et al. (2005), Zeidan et al. (2006), Abuzar et al. (2011), ELMetwally et al. (2011), Adeniyan (2014), Farnia \& Mansouri (2014), Kandil (2014), Eszter (2015) and Sarwar et al. (2016).

\section{Hybrids performance}

Data presented in Table 2 showed significant differences between maize hybrids in 2014 season for ear height. SC-176 hybrid recorded the highest values of ear height $143.30 \mathrm{~cm}$, whereas, the shortest one was obtained by SC-168 hybrid in 2014 season. Height of ear height can vary depending on the hybrid and growing condition (Gyner-Hegyi et al., 2002). The hybrid of SC-176 surpassed all tested crosses in grain yield (kg/fad). Otherwise SC-162 and SC168 were the lowest grain yield $(\mathrm{kg} / \mathrm{fad})$ in 2014 season . The superiority of SC176 might have been due to lower percentage of barren plants, longer ears, higher weight of grains/ear and higher shilling percentage. Otherwise, the lower potential ability of SC-162 and SC-168 may be attributed to the lower values of ear characteristics and shelling percentage. Similar results were reported by Azam et al., (2007), Compean et al. (2009), Sharifi et al. (2009), Alias et al. (2010), Gozubenli (2010), EL-Metwally et al. (2011) and Hafez et al. (2015).

\section{The interaction effects}

The interaction effects of plant density with nitrogen fertilizer on plant height and grain yield are presented in Table 4. The combined treatment 21000 plants/fad with $150 \mathrm{kgN} /$ fad gave the highest values of 193.33 and $192.78 \mathrm{~cm}$ for plant height in 2014 and 2015, respectively. Otherwise, the lowest value of plant height $(174.00 \mathrm{~cm})$ was recorded with 33600 plants/fad along with $90 \mathrm{kgN} / \mathrm{fad}$ in 2014 season and $172.78 \mathrm{~cm}$ from 27300 plants/fad with $90 \mathrm{kgN} / \mathrm{fad}$ in 2015 season. The highest values of grain yield was obtained from 33600 plants/fed along the $150 \mathrm{kgN} / \mathrm{fad}$, while the lowest value $(3685.89 \mathrm{Kg} / \mathrm{fad}$ in 2014 season and $3509.80 \mathrm{~kg} / \mathrm{fad}$ in 2015 season) obtained with 21000 plants/fed along with $90 \mathrm{kgN} / \mathrm{fad}$ in both seasons. These results are in agreement with those mentioned by Shoa et al. (2009), Bello et al. (2010), Rafiq et al. (2010), Dawadi \& Sah (2012) and Ayman \& Samier (2015). Regarding to the interaction effect between plant densities and maize hybrid on ear height in 2014 season (Table 5), it could be reported that highest ears were obtained at planting 33600 plants/fad and from SC-176, but the shortest ear height was resulted through planting 27300 plants/fad and using SC-168 hybrid. 
TABLE 4. Effect of the interaction between N-rates and plant densities on plant height, grain yield and nitrogen use efficiency of maize.

\begin{tabular}{|c|c|c|c|c|c|c|}
\hline \multirow{4}{*}{$\begin{array}{l}\text { N-rates } \\
\text { (kg/fad) } \\
\text { (A) }\end{array}$} & \multicolumn{6}{|c|}{ Plant height (cm) } \\
\hline & \multicolumn{3}{|c|}{2104 season } & \multicolumn{3}{|c|}{2015 season } \\
\hline & \multicolumn{3}{|c|}{ Plant densities (Plant/fed.) (B) } & \multicolumn{3}{|c|}{ Plant densities (Plant/fed.) (B) } \\
\hline & 21000 & 27300 & 33600 & 21000 & 27300 & 33600 \\
\hline 90 & 186.34 & 180.33 & 174.00 & 179.56 & 172.78 & 172.89 \\
\hline 120 & 185.89 & 174.56 & 177.56 & 184.78 & 179.67 & 176.89 \\
\hline 150 & 193.33 & 184.56 & 179.56 & 192.78 & 187.33 & 181.55 \\
\hline L.S.D 5\% & & 2.38 & & & 2.09 & \\
\hline \multirow{4}{*}{$\begin{array}{l}\text { N-rates } \\
(\mathrm{kg} / \mathrm{fad}) \\
\text { (A) }\end{array}$} & \multicolumn{6}{|c|}{ Grain yield (kg/fad) } \\
\hline & \multicolumn{3}{|c|}{2104 season } & \multicolumn{3}{|c|}{2015 season } \\
\hline & \multicolumn{3}{|c|}{ Plant densities (Plant/fad) (B) } & \multicolumn{3}{|c|}{ Plant densities (Plant/fad) (B) } \\
\hline & 21000 & 21000 & 27300 & 21000 & 27300 & 33600 \\
\hline 90 & 3685.89 & 4014.11 & 4221.93 & 3509.80 & 3966.20 & 4237.80 \\
\hline 120 & 3875.51 & 4135.91 & 4368.00 & 3738.00 & 4116.00 & 4424.00 \\
\hline 150 & 4091.73 & 4297.69 & 4631.2 & 3985.80 & 4208.40 & 4510.80 \\
\hline L.S.D 5\% & & NS & & & 0.78 & \\
\hline \multirow{4}{*}{$\begin{array}{l}\text { N-rates } \\
(\mathrm{kg} / \mathrm{fad}) \\
(\mathrm{A})\end{array}$} & \multicolumn{6}{|c|}{ Nitrogen use efficiency (NUE) } \\
\hline & \multicolumn{3}{|c|}{2104 season } & \multicolumn{3}{|c|}{2015 season } \\
\hline & \multicolumn{3}{|c|}{ Plant densities (Plant/fad) (B) } & \multicolumn{3}{|c|}{ Plant densities (Plant/fad) (B) } \\
\hline & 21000 & 21000 & 27300 & 21000 & 21000 & 27300 \\
\hline 90 & 40.95 & 44.60 & 46.83 & 39.00 & 44.06 & 47.09 \\
\hline 120 & 32.29 & 34.47 & 36.40 & 31.16 & 34.29 & 36.87 \\
\hline 150 & 27.28 & 28.65 & 30.87 & 26.57 & 28.05 & 30.09 \\
\hline L.S.D $5 \%$ & \multicolumn{3}{|c|}{1.00} & \multicolumn{3}{|c|}{1.28} \\
\hline
\end{tabular}

Data in Table 5 show that planting 33600 plants/fad from SC-176 hybrid produced the greatest 500 grains weight in 2015 season. Also, the data in same table indicated that planting 33600 plants/fed from SC-176 hybrid gave the greatest grain yield in 2014 season. The smallest grain yield was obtained at planting 21000 plants/fad from SC- 168 in 2014 season.

As shown in Table 6 the highest values of grain yield were obtained with the second order of interaction between ( $\mathrm{N}$ x cross) $150 \mathrm{kgN} / \mathrm{fad}, 33600$ plants/fad

Egypt. J. Agron. 38, No. 3(2016) 
and SC-176 hybrid in 2014 season. As well as ear diameter were obtained with interaction between $150 \mathrm{kgN} / \mathrm{fad}, 21000$ plants/fad and SC-162 hybrid, while the lowest values were obtained with interaction of $90 \mathrm{kgN} / \mathrm{fad}, 21000$ plants/fad and SC-168 hybrid in grain yield 2014 season. Moreover, same result could be found for the interaction between $90 \mathrm{kgN} / \mathrm{fad}, 33600$ plants/fad and SC-176 hybrid in ear diameter 2015 season.

\section{Nitrogen use efficiency}

Grain yield $\mathrm{kg} / \mathrm{fad} /$ ittrogen applied, $\mathrm{kg} / \mathrm{fad}$

Nitrogen use efficiency in terms of productivity factor clearly showed that application of nitrogen with low rates caused a higher value on nitrogen use efficiency. Data in Table 2 show that there was significant decrease in NUE in both 2014 and 2015 seasons by increasing $\mathrm{N}$ rates $150 \mathrm{kgN} / \mathrm{fad}$. This might be due to that any small amount of nitrogen applied could give a large yield response. This result was in agreement with that of Gauar et al. (1992) who reports that NUE is generally the greatest with low rates of applied $\mathrm{N}$ and decreases as the amount of $\mathrm{N}$ applied increases. Also, there was significant increase in NUE by applying plant densities in both seasons. The highest value was obtained with 33600 plant/fad followed by $27300 \mathrm{plant} / \mathrm{fad}$ and 21000 plant/fad in both seasons. Data in Table 4 indicate that the combination between $90 \mathrm{~kg} \mathrm{~N} / \mathrm{fad}$ and 33600 plant/fad produced the maximum NUE 46.83 in the first season and 47.09 in the second season. Otherwise, the minimum one was 27.28 and 26.57 in the first and second season, respectively, produced from adding $150 \mathrm{kgN} / \mathrm{fad}$ and $21000 \mathrm{plant} / \mathrm{fad}$. Plant densities and maize hybrid interaction was significant on NUE in 2014 season. The most amount of NUE was 45.29 observed with application of 21000 plant/fad and SC-176.

Data in Table 6 showed that interaction among N-rates, plant densities and maize hybrid was significant on NUE in the 2014 season. The highest values of NUE were 47.82 in 2014 season, produced from $90 \mathrm{~kg} \mathrm{~N} / \mathrm{fad}, 33600$ plant/fad and SC-176.

\section{Economic evaluation}

Data in Table 7 show that net return increased by increasing nitrogen rates. Net return showed considerable variation due to the nitrogen rates indicating that significantly net return $6553.94 \mathrm{~L} . \mathrm{E} / \mathrm{fad}$ were obtained by $150 \mathrm{~kg} / \mathrm{fad}$, followed by $120 \mathrm{~kg} / \mathrm{fad}$ with $6166 \mathrm{~L} . \mathrm{E} / \mathrm{fad}$ and the lowest net return $5803.22 \mathrm{~L} . \mathrm{E} / \mathrm{fad}$ were obtained by $90 \mathrm{~kg} / \mathrm{fad}$. Similar results of economics increased nitrogen rates were also reported by Bhatt Spadana (2012). Net return increased by increasing plant densities applying 33600 plant/fad gave the highest value $6847.78 \mathrm{~L} . \mathrm{E} / \mathrm{fad}$, while the smallest value was 5474.19 L.E/fad resulted from applying 21000 plant/fad. Regarding to maize hybrid, higher net return 6339.39 L.E/fad was obtained by SC-176 which was comparable with SC-162 (6138.92 L.E/fad) and SC-168 (6045.78 L.E/fad). The treatment combination of $150 \mathrm{~kg} \mathrm{~N} / \mathrm{fad}$ with 33600 plant/fad and SC-176 maize hybrid due to interaction gave the greatest net return which equal $7413.50 \mathrm{~L} . \mathrm{E} / \mathrm{fad}$, while the lowest net return was 4820.00 L.E/fad produced from $90 \mathrm{~kg} \mathrm{~N} / \mathrm{fad}, 21000$ plant/fad and SC-168 maize hybrid . 

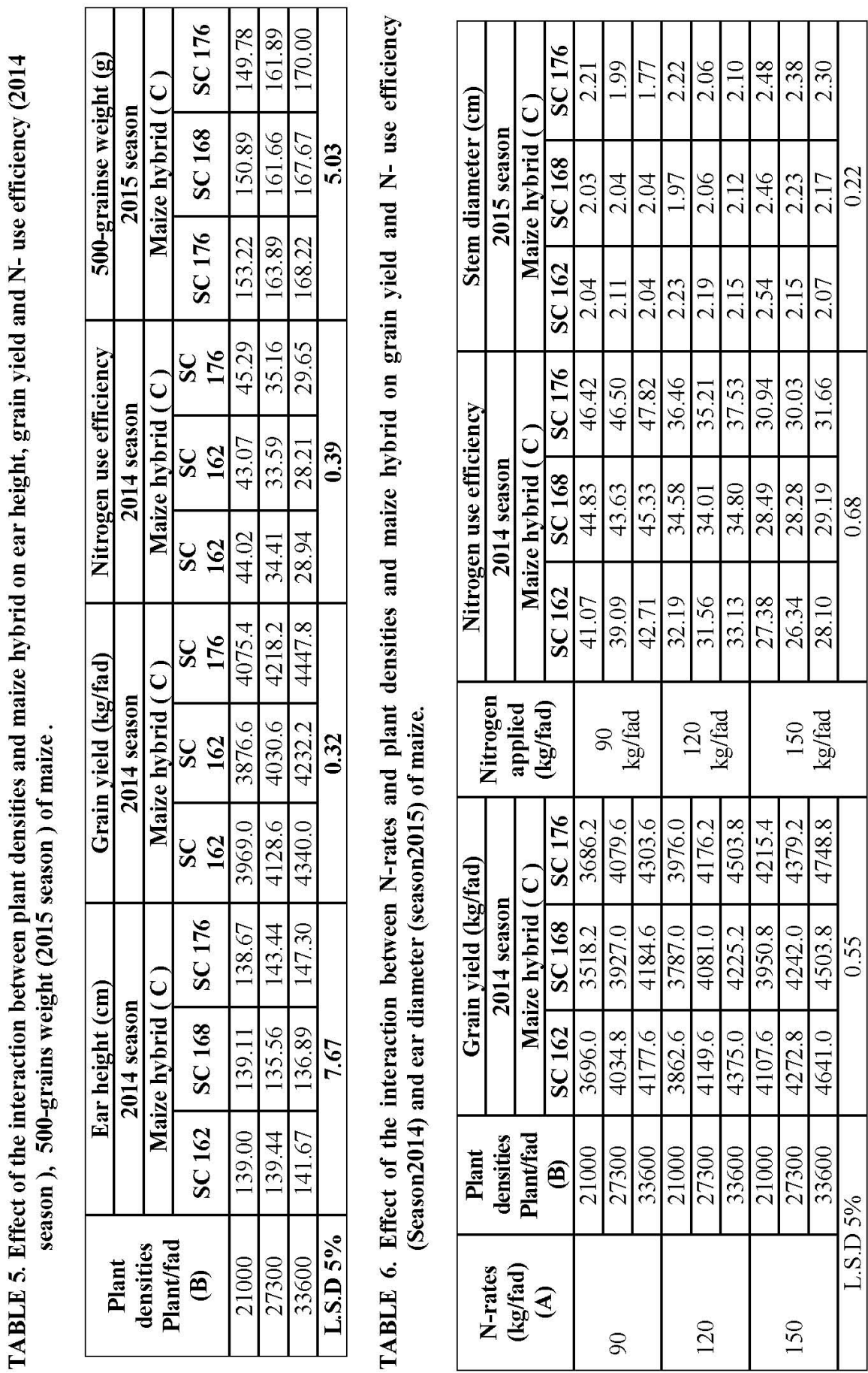
TABLE 7. Total costs, Gross return (L.E./fad) and benefit : cost ratio (BCR) as affected by nitrogen rates, plant densities and maize hybrids (average of 2014/2015 season

\begin{tabular}{|c|c|c|c|c|c|c|}
\hline $\begin{array}{c}\text { N-rates } \\
\text { (kg/fad) } \\
\text { (A) }\end{array}$ & $\begin{array}{c}\text { Plant } \\
\text { densities } \\
\text { (plant/fad) } \\
\text { (B) }\end{array}$ & $\begin{array}{c}\text { Maize } \\
\text { Hybrid } \\
\text { (C) }\end{array}$ & $\begin{array}{c}\text { Total } \\
\text { costs } \\
\text { L.E./fad }\end{array}$ & $\begin{array}{c}\text { Gross } \\
\text { return } \\
\text { L.E./fad }\end{array}$ & $\begin{array}{c}\text { Net } \\
\text { return } \\
\text { L.E./fad }\end{array}$ & $\begin{array}{c}\text { Benefit : } \\
\text { cost ratio } \\
\text { (BCR) }\end{array}$ \\
\hline \multirow{9}{*}{$\begin{array}{c}90 \\
\mathrm{~kg} / \mathrm{fad}\end{array}$} & \multirow{3}{*}{$\begin{array}{c}21000 \\
\text { (plant/fad) }\end{array}$} & SC162 & \multirow{3}{*}{4000.00} & 9080.75 & 5080.75 & 1.27 \\
\hline & & SC168 & & 8820.00 & 4820.00 & 1.21 \\
\hline & & SC176 & & 9082.50 & 5082.50 & 1.27 \\
\hline & \multirow{3}{*}{$\begin{array}{c}27300 \\
\text { (plant/fad) }\end{array}$} & SC162 & \multirow{3}{*}{4045.00} & 9997.75 & 5952.75 & 1.47 \\
\hline & & SC168 & & 9723.00 & 5678.00 & 1.40 \\
\hline & & SC176 & & 10204.25 & 6159.25 & 1.52 \\
\hline & \multirow{3}{*}{$\begin{array}{c}33600 \\
\text { (plant/fad) }\end{array}$} & SC162 & \multirow{3}{*}{4090.00} & 10419.50 & 6329.50 & 1.55 \\
\hline & & SC168 & & 10514.00 & 6424.00 & 1.57 \\
\hline & & SC176 & & 10792.25 & 6702.25 & 1.64 \\
\hline \multirow{9}{*}{$\begin{array}{c}120 \\
\mathrm{~kg} / \mathrm{fad}\end{array}$} & \multirow{3}{*}{$\begin{array}{c}21000 \\
\text { (plant/fad) }\end{array}$} & SC162 & \multirow{3}{*}{4060.00} & 9457.00 & 5397.00 & 1.33 \\
\hline & & SC168 & & 9261.00 & 5201.00 & 1.28 \\
\hline & & SC176 & & 9817.50 & 5757.50 & 1.42 \\
\hline & \multirow{3}{*}{$\begin{array}{c}27300 \\
\text { (plant/fad) }\end{array}$} & SC162 & \multirow{3}{*}{4105.00} & 10379.25 & 6274.25 & 1.53 \\
\hline & & SC168 & & 10295.25 & 6190.25 & 1.51 \\
\hline & & SC176 & & 10267.25 & 6162.25 & 1.50 \\
\hline & \multirow{3}{*}{$\begin{array}{c}33600 \\
\text { (plant/fad) }\end{array}$} & SC162 & \multirow{3}{*}{4150.00} & 11002.25 & 6852.25 & 1.65 \\
\hline & & SC168 & & 10778.25 & 6628.25 & 1.60 \\
\hline & & SC176 & & 11189.50 & 7039.50 & 1.70 \\
\hline \multirow{9}{*}{$\begin{array}{c}150 \\
\mathrm{~kg} / \mathrm{fad}\end{array}$} & \multirow{3}{*}{$\begin{array}{c}21000 \\
\text { (plant/fad) }\end{array}$} & SC162 & \multirow{3}{*}{4120.00} & 10113.25 & 5993.25 & 1.45 \\
\hline & & SC168 & & 9959.25 & 5839.25 & 1.42 \\
\hline & & SC176 & & 10216.50 & 6096.50 & 1.48 \\
\hline & \multirow{3}{*}{$\begin{array}{c}27300 \\
\text { (plant/fad) }\end{array}$} & SC162 & \multirow{3}{*}{4165.00} & 10393.25 & 6229.25 & 1.50 \\
\hline & & SC168 & & 10697.75 & 6532.75 & 1.57 \\
\hline & & SC176 & & 10806.25 & 6641.25 & 1.59 \\
\hline & \multirow{3}{*}{$\begin{array}{c}33600 \\
\text { (plant/fad) }\end{array}$} & SC162 & \multirow{3}{*}{4210.00} & 11352.25 & 7142.25 & 1.70 \\
\hline & & SC168 & & 11308.50 & 7098.50 & 1.69 \\
\hline & & SC176 & & 11623.50 & 7413.50 & 1.76 \\
\hline \multirow{9}{*}{$\begin{array}{l}\text { Mean of } \\
\text { factors }\end{array}$} & \multicolumn{2}{|c|}{$90 \mathrm{~kg} / \mathrm{fad}(\mathrm{A} 1)$} & 4045.00 & 9848.22 & 5803.22 & 1.43 \\
\hline & \multicolumn{2}{|c|}{$120 \mathrm{~kg} / \mathrm{fad}(\mathrm{A} 2)$} & 4105.00 & 10271.92 & 6166.92 & 1.50 \\
\hline & \multicolumn{2}{|c|}{$150 \mathrm{~kg} / \mathrm{fad}(\mathrm{A} 3)$} & 4165.00 & 10718.94 & 6553.94 & 1.57 \\
\hline & \multicolumn{2}{|c|}{$21000($ plant/fad $)(\mathrm{B} 1)$} & 4060.00 & 9534.19 & 5474.19 & 1.35 \\
\hline & \multicolumn{2}{|c|}{$21000($ plant/fad) (B2) } & 4105.00 & 10307.11 & 6202.11 & 1.51 \\
\hline & $21000(\mathrm{pla}$ & $\mathrm{ad})(\mathrm{B})$ & 4150.00 & 10997.78 & 6847.78 & 1.65 \\
\hline & $\mathrm{SC} 16$ & & 4105.00 & 10243.92 & 6138.92 & 1.50 \\
\hline & SC 16 & & 4105.00 & 10150.78 & 6045.78 & 1.47 \\
\hline & $\mathrm{SC} 16$ & & 4105.00 & 10444.39 & 6339.39 & 1.54 \\
\hline
\end{tabular}

\section{References}

Abdel-Hameed, I.M. (2005) Effect of sources and levels of nitrogen fertilizer on productivity of maize. The $11^{\text {th }}$ Conference of Agronomy, Agron. Dept., Fac. Agric., Assiut Univ., 15-16, 2005. pp.133-149.

Abdrabou,R.Th.(1996) Response of maize yield to ethephon treatment and nitrogen fertilization rates under two row direction. Annals Agric.Sci., Fac.Agric., Ain Shams Univ., Egypt, 41(2), 683-695. 
Abuzar, M.R., Sadozia, G.U., Baloch, M.S., Baloch, A.A., Shah, I.H., Javaid, T. and Hussain, N. (2011) Effect of plant population densities on yield maize. $J$. Anim. Plant Sci.21(4), 692-695.

Adeniyan, O.N. (2014) Effect of different population densities and fertilizer rates on the performance of different maize varieties in two rain forest agro ecosystems of south West Nigeria. Afr. J. Plant Sci. 8 (8), 410-415.

Aiad, M.A., Moursi, E.A., EL-dissoky, R.A. and Amer, M.M. (2014) Response of maize crop to irrigation under different rates and doses of nitrogen fertilization in the North Nile Delta region. J. Soil Sci. Agric. Eng. Mansoura Univ. 5 (1), 77-92.

Akmal, M., Hamed, UR-Rehman, Farhatullah, Asim, M. and Akbar, H. (2010) Response of maize varieties to nitrogen application for leaf area profile, crop growth, yield and yield components. Pak. J. Bot. 42 (3), 1941-1947.

Alessi,J. and Power, J.F. (1975) Response of an early maturing corn hybrid to planting date and population in the northern plains. Agron .J. 67, 762-765.

Alias, M.A., Bukhsh, H.A., Ahmad, R., Malik, A.U., Hussain, S. and Ishaque, M. (2010) Agro physiological traits of three maize hybrids as influenced by varying plant density. J. Animal and Plant Sci. 20 (1), 453-459.

Amer, E.A., EL-Shenawy, A.A., Mosa, H.E. and Motawei, A.A. (2004) Effect of spacing between hills and number of plant per hill on growth, yield and its components of six maize crosses. J. Agric. Rws., Tanta Univ. 30 (3), 6601-6615.

Farnia, A. and Mansouri, M. (2014) Effect of plant density to yield and yield components of maize (Zea mays L.). Bulletin Envir. Pharma. Life Sci. 3 (Special Issue V), 123-127.

Ayman, H.A. and Samier, K.A. (2015) Maize productivity as affected by plant density and nitrogen. Int. Curr. Microbial. App Sci. 4(6), 870-877.

Azam, S., Ali, M., Amin, M., Bibi, S. and Arif, M. (2007) Effect of plant population on maize hybrids.Peshawar, Pakistan Agric. J. Bio. Sci. 2 (1).

Barbar, S.A. (1976) Efficient fertilizer use In: "Agronomic Research for Food". Patterson. F.L. (Ed), pp. 13-29, American Society of Agronomy special Publication, 26, Madison, USA.

Bhatt Spandana, P. (2012) Response of sweet corn hybrid to varying plant densities and nitrogen levels . Afr. J. Agric.Res.7 (46), 6158-6166.

Bello, O.B., Abdulmaliq, S.Y., Afolabi, M.S. and Ige, S.A. (2010) Correlation and path coefficient analysis of yield and agronomic characters among opess pollinated maize varities and their FL hybrid in a diallel cross. Afr. J. Biotechnol. 9 (18), 2633-2639.

CIMMYT (1988) "From Agronomic Data to Farmer Recommendation: An Economic Work Book” D.F: pp. 31-33.

Egypt. J. Agron. 38, No. 3(2016) 
Compean, S.V., Has, V. and Has, I. (2009) Plant population effects on few yield parameters in some turda maize hybrids. Res. J. Agric. Sci. 41(1).

Cottenie, A., Verloo, M., Mjkiekens, L., Velghe, G. and Comertynck, R. (1982)

"Chemical Analysis of Plant and Soil". Lab. Anal. And Agrochem. State Univ., Gent., Belgium, Chapter 2 and 3 pp. 14-54.

Dawadi, R. and Sah, S.K. (2012) Growth and yield of hybrid maize (Zea mays L.) in relation planting density and nitrogen levels during winter season in Nepal. Tro. Agric. Res. 23 (3), 218-227.

Davoyd, D., Mehdi, T. and Mohammed, R.Z. (2010) Effects of nitrogen on yield and nitrogen efficiency of silage corn hybrid SC.604 at different plant density. J . Res. Agric. Sci. 6 (2), 121-129.

Diwaker, B. and Oswalt, D.L. (1992) "Research Planning and Data Handling". ICRSAT . Andhra Pradesh, India . p. 89.

EL-Agamy, A.I., Morshed, G.A. Soliman, F.H. (1999) Performance of some yellow maize hybrids under different plant population densities and nitrogen fertilizer levels. J. Agric. Sci. Mansoura Univ. 24(3), 911-923.

EL-Metwally, E.A., EL-Deep, A.A, Safina, S.A. and Rabbani, B.G. (2011) Behavior of some maize hybrids cultivated with different plant dinsities. J. Plant Production, Mansoura Univ. 2 (3), 479-490.

Edmeades, G.O., Bolanose, J.A., Elings, A.J. M., Ribaut, J. M. and Banzigen, M. (2000) The role and regulation of the authesis-silking interval in maize. In: "Physiology and Modeling Kernel Set in Maize", M.E., K.J Boote (Ed.), pp. 43-73, West Gate, SSA, Madison, WI.

Eszter, M. (2015) Effect of plant density and row spacing on maize (Zea mays L.) grain yield in different crop year. Columella-J.Agric. and Envir. Sci. 2(1), 57-63.

Farnham, D.E. (2001) Row spacing Plant density and hybrid effects on corn grain yield and moisture. Agron. J. 93, 1049-1053.

Gauar, L.E., Grant, C.A., Gehl, D.T. and Bailey, L.D. (1992) Effects of nitrogen fertilization on grain protein content, nitrogen use efficiency of six spring wheat (Triticum aestivum L.) cultivars, in relation to estimated moisture supply. Canadian Journal of Plant Sci. 72, 235-241.

Gomez, K.A. and Gomez, A.A. (1991) "Statistical Procedures for Agricultural Research". $2^{\text {nd }}$ ed., pp. 95-109. Jhon Wiley and Sons Inc., New York.

Gozubenli, H. (2010) Influence of planting and plant density on the performance of maize hybrids in the eastern Mediterranean conditions. Int. J. Agric. Biol. 12, 556560 .

Gyner-Hegyi, Z., Kizmus, L., Zsubori, L. and Marton, L.C. (2002) Plant height and height of the maize ear in maize (Zea mays L.) at different locations and different plant densities. Acta Agr. Hungarica, 50, 75-84.

Egypt. J. Agron. 38, No. 3 (2016) 
Hafez, E.M. and Abdelaal, Kh. A.A. (2015) Impact of nitrogen fertilization levels on morphysiological characters and yield quality of some maize hybrid (Zea mays L.). Egypt. J. Agron. 37 (1), 35-48.

Hussein, Samira M.A., Haikel, M.A. and El-Masry, M.A. (1998) Effect of some preceding crops, hill space and nitrogen fertilization on yield attributes and grain yield of maize under reclaimed sandy soil conditions in east delta. Egypt Soc.Crop Sci.\& Fac.Agric. Suez Canal Univ. The eight Coference of Agronomy, Nov. 28-29, Abst., p.35.

Kandil, E.E. (2014) Determine independent population density for each maize hybrid (Zea mays L.). $2^{\text {nd }}$ International Conference on Agric. and Biotechnology, 79 (6), 30-35.

Karasu, A.Z. (2012) Effect of nitrogen levels on grain yield and some attributes of some hybrid maize cultivars (Zea mays indentate sturt.) grown for silage as second crop. Bulg. J. Agric. Sci. 18 (1), 42-48.

Kirtok,Y.(1998) “Corn Production and Using”. Kacaoluk Publication. Istanbul, p. 445.

Lamkey, K.R. (1994) Genetic contrbution to yield improvement in maize. Agron. Abst., Annual Meeting, American Soc. Agron., 13-18 Nov., pp.132-133

Maddonni, G.A., Cirilo, A.G. and Otegui, M.E. (2006) Row width and maize grain yield. Agron. J. 98, 1532-1543.

Mohammed, Amany M. (1999) Evaluation of some yellow hybrids maize (Zea mays L.) under different levels of plant densities and nitrogen fertilization. M.Sc. Thesis, Fac. Agric., Kafrelsheikh, Tanta Univ., Egypt.

Nasser, M.M.I., Aziz, Manal A., Gendy, A.A.S. and EL-Saiad, I.A. (2015) Response of maize varieties to $\mathrm{N}$-fertilizer rates under drainage conditions in clay soil. J. soil Sci. Agric. Eng. Mansoura Univ. 6 (2), 295-307.

Rafiq, M.A., Ali, A., Malik, M.A. and Hussain, M. (2010) Effect of fertilizer levels and plant densities on yield and protein contents of autumn planted maize. Pak. J. Agri. Sci. 47(3), 201-208.

Saberali, S.F. (2007) Influence of plant density and planting pattern of corn on its growth and yield under competition with common lambsequarters (Chenopodium album L.) Pajouhesh and Azandeyi, 74,143-152.

Sangakkara, U.R., Bandaranayaka, P.S., Gajanayakaa, J.N. and Stamp, P. (2004) Plant population and yield of rainfed maize grown in wet and dry seasons of the tropics. Maydica, 49, 83-88.

Sarwar, F., Bahadur, M., Islam, K.M., Ray, K.T. and Ali, K.M. (2016) Yield and yield components of maize as affected by planting density. Inter. J. Plant Soil Sci. 9 (5),1-12.

Sencer, O. (1988) Effect of sowing rate and nitrogen on corn growing. Cukurova Univ. Tokat Agric.Faculty pub.No: 6, Tokat.

Egypt. J. Agron. 38, No. 3(2016) 
Sezer, I. and Yanbeyi, S. (1997) Plant density and nitrogen fertilizer effect on grain yield, yield components and some plant characters of popcorn in Carsamba plain .Turkey II. Field Crops Congress, 22-25 September 1997. Samsun, pp. 128-133.

Shahid, I., Khan, H.Z., Ehsanullah, Zamir, M.S., Marral, M.W. and Javeed, H.M. (2014) The effects of nitrogen fertilization strategies on the productivity of maize (Zea mays L.) hybrids. Zemdirbyste. Agric. 101(3), 249-256.

Shakarami, G. and Rafiee, M. (2009) Response of corn (Zea mays L.) to planting pattern and density in Iran. Agric. J. Env. Sci. 5 (1), 69-73.

Sharifi, S.R., Sedeqi, M. and Gholipouri, A. (2009) Effect of population density on yield and yield attributes of maize hybrids. Iran. Res. J. Biol. Sci. 4(4), 375-379.

Shoa, M.M., Golbashy, M., Farsi, S., Khorasani, M. and Beirag, A. (2009) Evaluation of correlation between yield and its dependant trait in single cross corn hybrids under drought stress. Abstract book of $1^{\text {st }}$ regional conference on tropical crops production under environmental stresses condition. Islamic Azad Univ., Khozestan Sci., Reseach Branch. p.72.

Soliman, F.H.S., Morshed, G.A., Ragheb, M.M.A. and Osman, M. Kh. (1999) Correlation and path coefficient analysis in four yellow maize hybrids under different levels of population densities and nitrogen fertilization. Bull. Fac. Agric., Cairo Univ. 50, 639-658.

Soliman, F.H.S., Abd El-Aal, A.I.N., Mahmoud, A.A., Ahmed, A.A. and Ahmed, M.A. (2004) Maize production in new lands at Toshka and East El-Ewinat Regions. Bull.Fac.Agric. Cairo Univ. 55 (2), 237-264.

Soliman, F.H.S., Ahmed, A.A. and Abd RI-Azeem, M.E.M. (2005) Maize productivety under different plant densieties in Toshka Region, South Valley of Egypt. Egypt. J. Appl. Sci. 20 (5B), 671-695.

Steel, R. G. B., Torrrie, J. H. and Dicky, D. A. (1997) "Principles and Procedures of Statistics. A Biometrical Approach". $3^{\text {rd }}$ ed. pp. 352-358, McGraw Hill. Inc. Book Co. N.Y. (USA.).

Tantawy, A.A., Yousef, M.A. and Meky, M.S. (1998) The effect of plant population and weed control treatment on yield, yield components and chemical contents of some maize varieties (Zea mays L.). Egypt, Soc. Crop Sci. \& Fac. Agric. Suez Canal Univ. The Eight Conference of Agronomy, Nov. 28-29, Abst., p. 37.

Widdicombe, D.W. and Thelen, K.D. (2002) Row width and plant effect on corn grain production in northern corn belt. Agron. J. 94, 1020-1023.

Zeidan, M.S., Amany, A. and Bahr EL-Kramany, M.F. (2006) Effect of N-fertilizer and plant density on yield and quality of maize in sandy soil. Res. J. Agric. Biol. Sci. 2 (4), 156-161. 


\section{إستجابة بعض هجن الأرة الثامية الصفراء تحت مستويات مختلفة من الكثافات النباتية والتسميد الآزوتى بمنطقة توشكى

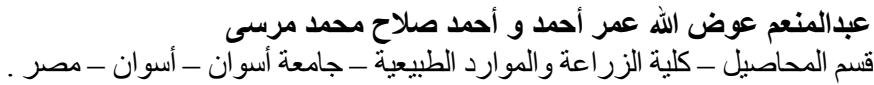

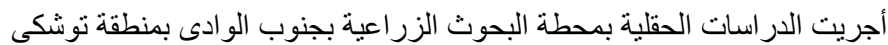

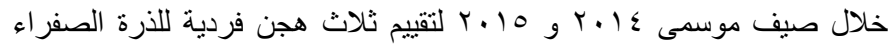

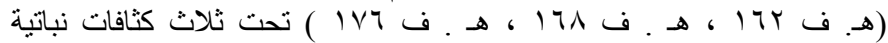

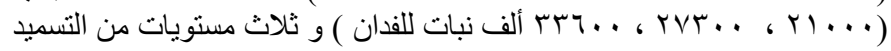

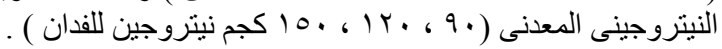

$$
\text { ويمكن تلخيص أهم النتائج المتحصل عليها فيما يلى : }
$$

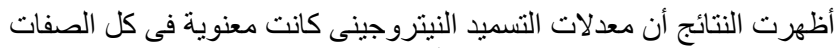

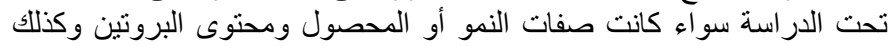

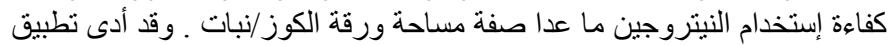

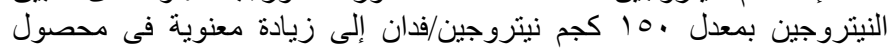

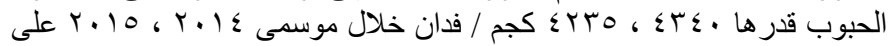

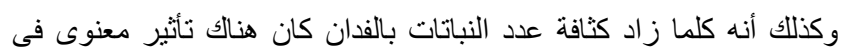

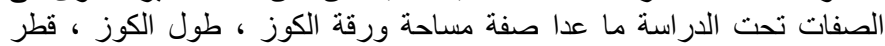

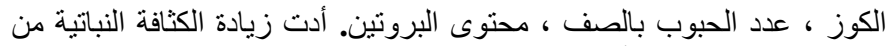

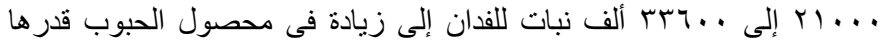

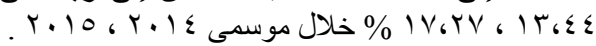

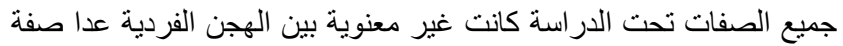

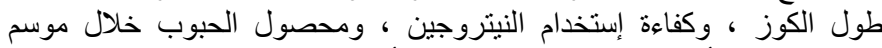

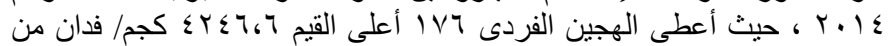

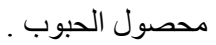

وكانت تأثثير التداخلات بين كل من التسميد النيتروجين والكثافات النباتية

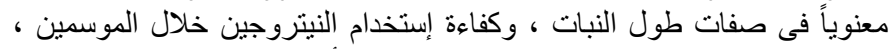

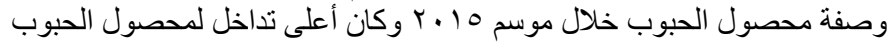

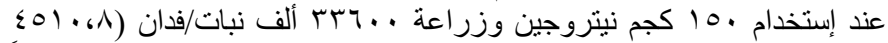

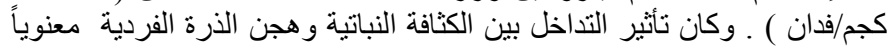

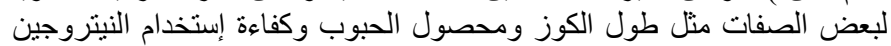

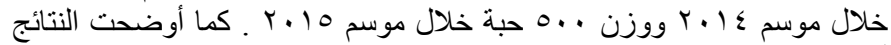

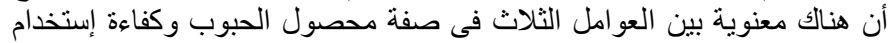

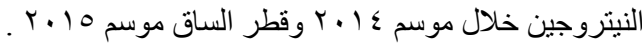

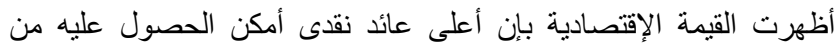

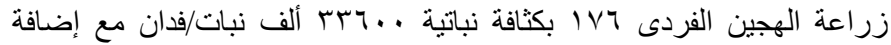

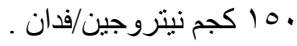

Egypt. J. Agron. 38, No. 3(2016) 